\title{
Diversi sebagai bentuk penyelesaian perkara pidana anak di tingkat penyidikan dalam kasus kejahatan kesusilaan di wilayah hukum Polda Jawa Timur
}

\section{Diversion as a form of child criminal settlement at the level of investigation in cases of crimes against morality in the jurisdiction of East Java Police Department}

\author{
Fahmi Noor Adly ${ }^{\bowtie}$ \\ Polres Bojonegoro \\ Bojonegoro, 62113, Jawa Timur, Indonesia \\ E-mail corresponding author: fahmi.noorald@yahoo.com
}

\begin{abstract}
Abstrak
Fenomena anak yang berhadapan dengan hukum menarik perhatian untuk dikaji lebih jauh. Sebagaimana diketahui bahwasanya bagi seorang pelanggar hukum berusia dibawah 18 tahun, segala bentuk penyelesaian perkara akan berdampak pada perkembangan kepribadian anak. Maka dari itu, diversi merupakan salah satu jalan yang perlu dipertimbangkan oleh penyidik untuk tetap melanjutkan perkara ataupun menghentikannya. Penelitian ini bertujuan untuk menganalisis penerapan diversi sebagai bentuk penyelesaian perkara pidana anak di tingkat penyidikan dalam kasus kejahatan kesusilaan di wilayah hukum Polda Jatim serta untuk menganalisis hal-hal yang menjadi faktor penghambat dalam penerapan diversi. Adapun metode penelitian yang digunakan ialah kualitatif dengan teknik pengumpulan datanya melalui wawancara, catatan lapangan, dan dokumentasi. Hasil penelitian ini menunjukkan bahwa dalam pelaksanaan diversi, adapun penyidik yang berperan ialah penyidik khusus anak yang mana dalam pelaksanaan penangkapan, penahanan, dan pemeriksaan anak dilakukan dalam suasana kekeluargaan, serta penyidik wajib meminta pertimbangan atau saran dari pembimbing kemasyarakatan. Sedangkan faktor penghambat dalam pelaksanaan diversi selama ini yang berlangsung di wilayah hukum Polda Jatim, sepenuhnya dikarenakan adanya permasalahan internal dan eksternal.
\end{abstract}

Kata kunci: diversi; pidana; anak; penyidik; kepolisian

\begin{abstract}
The phenomena of juvenile crime is always interesting to be studied. As it is known, any form of case settlement involving child offenders under the age of 18 will affect their personality development. Therefore, diversion becomes one of the means to be considered by the investigators to decide on continuing or dropping the case. This research aims to analyze the application of diversion as a form of juvenile crime resolution at the investigation level in cases of crimes against morality in the jurisdiction of East Java Police Department. In addition, the study also aims to identify the inhibiting factors in the implementation of diversion. The study was conducted qualitatively, collecting data through interviews, field observations, and documentation. The results show that in the implementation of diversion, the acting investigators are the so called special investigators. These investigators conduct arrest, detention, and questioning of the child offenders in a humane and friendly manner. The investigators are also obliged to seek considerations from community supervisors. Moreover, factors inhibiting the implementation of diversion within the jurisdiction of East Java Police Department are categorized into internal and external problems.
\end{abstract}

Keywords: diversion; criminal; children; investigator; police

\section{Pendahuluan}

Anak sebagai pelaku tindak pidana disebut dengan anak yang delinkuen atau dalam hukum pidana dikatakan sebagai juvenile delinquency. Juvenile delinquency adalah setiap perbuatan atau tingkah laku seorang anak dibawah umur 18 Tahun dan belum kawin yang merupakan pelanggaran berlaku serta dapat membahayakan perkembangan pribadi si anak (Atmasasmita 1983). Untuk itu, dalam menghadapi dan menanggulangi berbagai masalah tersebut, perlu dipertimbangkan kedudukan anak dengan segala ciri dan sifat yang khas sebagai pelaku tindak pidana. Tidak melihat apakah perbuatan 
itu berdasarkan pikiran, perasaan dan terhadap norma-norma hukum yang kehendaknya namun harus juga melihat berbagai hal yang dapat mempengaruhi anak berbuat suatu tindak pidana, sehingga diperlukan peran dari orangtua dan masyarakat sekelilingnya.

Diversi menjadi salah satu jalan terbaik dalam penyelesaian perkara pidana anak (Stickland 2004; Ratomi 2013). Tujuan divesri dengan konsep restorative justice yang penanganannya selalu mengutamakan dijalankan dengan memperhitungan pengaruh yang lebih luas terhadap korban, pelaku dan masyarakat (Yudaningsih 2014; Sosiawan 2016; Hartono 2015; Hambali 2019; Mimi et al. 2014; Edyanto 2017). Diversi merupakan wewenang dari aparat penegak hukum yang menangani kasus tindak pidana untuk mengambil tindakan meneruskanperkara atau mengehentikan perkara, mengambil tindakan tertentu sesuai dengan kebijakan yang dimiliknya (Marlina 2010). Konsep diversi didasarkan pada kenyataan bahwa proses peradilan pidana terhadap anak pelaku tindak pidana melalui sistem peradilan pidana lebih banyak menimbulkan bahaya daripada kebaikan. Alasan dasarnya yaitu pengadilan akan memberikan stigmatisasi terhadap anak atas tindakan yang dilakukannya seperti anak dianggap jahat, sehingga lebih baik untuk menghindarkannya ke luar sistem peradilan pidana (Marlina 2008; Pratama 2018; Harahap 2014).

Diversi dilakukan dengan alasan untuk memberikan suatu kesempatan kepada pelanggar hukum agar menjadi orang yang baik kembali melalui jalur non formal dengan melibatkan sumber daya masyarakat (Munajah 2015; Priamsari 2018; Rosyidah 2012). Diversi berupaya memberikan keadilan kepada kasus anak yang telah terlanjur melakukan tindak pidana sampai kepada aparat penegak hukum sebagai pihak penegak hukum (Ernis 2016; Wicaksono \& Pujiyono 2015). Kedua keadilan tersebut dipaparkan melalui sebuah penelitian terhadap keadaan dan situasi untuk memperoleh sanksi atau tindakan yang tepat (appropriate treatment) tiga jenis pelaksanaan program diversi dilaksanakan yaitu: a) Pelaksanaan kontrol secara sosial (social control orintation); b) Pelayanan sosial oleh masyarakat terhadap pelaku (social service orientation; c) Menuju proses restroative justice atau perundingan (balanced or restroative justice orientation).

Kajian empiris yang lain yaitu penelitian menunjukkan bahwa ada tiga fenomena penting yang perlu dicermati dalam kaitan dengan penyelenggaraan perlindungan anak yang berhadapan dengan hukum (Pratama et al. 2008). Pertama, adalah lemahnya perlindungan anak yang sedang berhadapan dengan hukum. Kedua, minimnya sarana dan prasarana didalam berlangsungnya proses anak yang berhadapan dengan hukum. Ketiga fenomena tersebut mengindikasikan bahwa penegakan dan perlindungan hukum, terutama perlindungan kepada anak masih sangat lemah dan perlunya peningkatan di sektor tersebut.

Sementara itu, tindak pidana dalam Kitab Undang-Undang Hukum Pidana dikenal dengan istilah strafbaar feit dan dalam kepustakaan tentang hokum pidana sering mempergunakan istilah delik, sedangkan pembuat undang-undang merumuskan suatu undang-undang mempergunakan istilah peristiwa pidana atau perbuatan pidana atau tindak pidana. Tindak pidana merupakan suatu istilah yang mengandung suatu pengertian dasar dalam ilmu hukum sebagai istilah yang dibentuk dengan kesadaran dalam memberikan ciri tertentu pada peristiwa hukum pidana. Tindak pidana mempunyai pengertian yang abstrak dari peristiwa-peristiwa yang kongkrit dalam lapangan hukum pidana, sehingga tindak pidana ilmiah dan ditentukan dengan jelas untuk dapat memisahkan dengan istilah yang dipakai sehari-hari dalam kehidupan masyarakat.

Tindak pidana merupakan suatu pengertian dasar dalam hukum pidana, tindak pidana adalah pengertian yuridis, lain halnya dengan istilah perbuatan atau kejahatan yang diartikan secara yuridis atau secara kriminologis (Wartono 2019; Plantika 2019; Rahmat 2019). Barda Nawawi Arief menyatakan "tindak pidana secara umum dapat diartikan sebagai perbuatan yang melawan hukum baik secara formal maupun secara materiil.

Unsur subjektif adalah unsur- unsur yang melekat pada diri si pelaku atau yang berhubungan dengan diri si pelaku, dan termasuk ke dalamnya yaitu segala sesuatu yang terkandung di dalam hatinya. Sedangkan unsur objektif adalah unsur-unsur yang ada hubungannya dengan keadaan-keadaan, yaitu 
di dalam keadaan-keadaan mana tindakan-tindakan dari si pelaku itu harus di lakukan. Unsur subjektif dari suatu tindak pidana itu adalah: (1) Kesengajaan atau ketidaksengajaan (dolus atau culpa); (2) Maksud atau Voornemen pada suatu percobaan atau pogging seperti yang dimaksud dalam Pasal 53 ayat 1 KUHP; (3) Macam-macam maksud atau oogmerk seperti yang terdapat misalnya di dalam kejahatan- kejahatan pencurian, penipuan, pemerasan, pemalsuan dan lain- lain; (4) Merencanakan terlebih dahulu atau voorbedachte raad seperti yang terdapat di dalam kejahatan haruslah diberikan arti yang bersifat pembunuhan menurut Pasal 340 KUHP.

Di sisi lain, pengertian anak secara nasional didasarkan pada batasan usia anak menurut hukum pidana, hukum perdata, hukum adat, dan hukum islam. Batas usia anak merupakan pengelompokan usia maksimum sebagai wujud kemampuan anak dalam setatus hukum, sehingga anak tersebut beralih status menjadi usia dewasa atau menjadi seorang subjek hukum yang dapat bertanggung jawab secara mandiri terhadap perbuatan- perbuatan dan tindakan-tindakan hukum yang dilakukan (Hadisuprapto 2010).

Kitab Undang-Undang Hukum Pidana mencantumkan beberapa pasal yang mengatur apabila seorang anak melakukan tindak pidana, yaitu Pasal 45, 46, dan 47. ketiga pasal tersebut disebutkan bahwa apabila seseorang yang belum genap berusia 16 tahun melakukan suatu perbuatan pidana maka ada tiga alternatif penghukuman yang dapat dijatuhkan, yaitu mengembalikan anak tersebut kepada orang tuanya, memasukannya kedalam rumah pemeliharaan anakanak nakal dan menghukum anak tersebut dengan mengurangi sepertiga dari pidana pokok yang diancamkan kepadanya (Soesilo 1994).

Beberapa hukum mengenai anak di antaranya seperti Hukum Perkawinan Indonesia Undang-Undang No.1 Tahun 1974 tentang Perkawinan Pasal 47 ayat 1 menyatakan bahwa anak yang belum mencapai umur 18 tahun atau belum pernah menikah ada dibawah kekuasaan orang tuanya selama mereka tidak dicabut kekuasaan orang tuanya. Pasal 50 ayat 1 berbunyi anak yang belum mencapai umur 18 tahun atau belum pernah menikah, yang tidak berada dibawah kekuasaan orang tua berada dibawah kekuasaan wali. Pasa 47 ayat 2 menyatakan bahwa orang tua mewakili kepentingan anak dalam melakukan perbuatan hukum. Perbuatan hukum yang dimaksud hanya menyangkut perbuatan hukum perdata dan bukan pidana. Contohnya adalah jual beli, sewa menyewa dan sebagainya. Namun dalam prakteknya tidak semua perbuatan hukum yang dilakukan anak, pelaksanaannya harus diwakili atau diwakilkan oleh orang tuannya meskipun anak itu belum berusia 18 tahun atau belum kawin. Pengertian perbuatan hukum tersebut, hanya sebatas perbuatanperbuatan yang secara umum belum selayaknya dilakukan oleh mereka yang belum berusia 18 tahun atau belum kawin.

Kemudian, hukum perdata menjamin hak-hak dasar anak sejak dia lahirkan bahkan sejak masih dalam kandungan. Pengertian anak dalam hukum perdata dimaksudkan pada pengertian sebelum dewasa. Karena menurut hukum perdata seorang anak yang belum dewasa sudah bias mengurus kepentingankepentingan keperdataannya. Untuk memenuhi kepentingan ini, maka diadakan peraturan tentang hendlichting, yaitu suatu pernyataan tentang seseorang yang belummencapai usia dewasa sepenuhnya (Subekti 2003). Lembaga hendlichting dianggap sudah tidak mengikuti dan tidak sesuai dengan perkembangan yang ada dalam masyarakat sekarang ini maka pada akhirnya dicabut. Terlebih setelah ditetapkannya batas umur dalam Undang-Undang No.1 tahun 1974 tentang Perkawinan.

Sementara itu penyidik menurut Pasal 1 butir ke-1 KUHAP adalah pejabat polisi Negara Republik Indonesia atau pejabat pegawai negeri sipil tertentu yang diberi wewenang khusus oleh undangundang untuk melakukan penyidikan. KUHAP lebih jauh lagi mengatur tentang penyidik dalam Pasal 6 , yang memberikan batasan pejabat penyidik dalam proses pidana. Adapun batasan pejabat dalam tahap penyidikan tersebut adalah pejabat penyidik POLRI dan Pejabat penyidik negeri sipil.

Penyidik pembantu selain diatur dalam Pasal 1 butir ke 1 KUHAP dan Pasal 6 KUHAP, terdapat lagi Pasal 10 yang mengatur tentang adanya penyidik pembantu disamping penyidik (Harahap 2005). Untuk mengetahui siapa yang dimaksud dengan orang yang berhak sebagai penyidik ditinjau dari segi instansi maupun kepangkatan, ditegaskan dalam Pasal 6 KUHAP. Dalam pasal tersebut ditentukan instansi dan kepangkatan seorang pejabat penyidik. Bertitik tolak dari ketentuan Pasal 6 KUHAP yang 
dimaksud, yang berhak diangkat sebagai pejabat penyidik antara lain adalah: (1) Pejabat Penyidik Penuh, pejabat polisi yang dapat diangkat sebagai pejabat "penyidik penuh", harus memenuhi syaratsyarat kepangkatan dan pengangkatan, yaitu: a) Sekurang-kurangnya berpangkat Pembantu Letnan Dua Polisi; b) Atau yang berpangkat bintara dibawah Pembantu Letnan Dua apabila dalam suatu sektor kepolisian tidak ada pejabat penyidik yang berpangka Pembantu Letnan Dua; c) Ditunjuk dan diangkat oleh Kepala Kepolisian Republik Indonesia; (2) Penyidik Pembantu, pasal 10 KUHAP menentukan bahwa Penyidik Pembantu adalah Pejabat Kepolisan Negara Republik Indonesia yang diangkat oleh Kepala Kepolisian Negara menurut syarat-syarat yang diatur dengan peraturan pemerintah.24 Pejabat polisi yang dapat diangkat sebagai "penyidik pembantu" diatur didalam Pasal 3 Peraturan Pemerintah Nomor 27 Tahun 1983. Peraturan Pemerintah Nomor 58 Tahun 2010.

Menurut ketentuan ini, syarat kepangkatan untuk dapat diangkat sebagai pejabat penyidik pembantu: a) Sekurang-kurangnya berpangkat Sersan Dua Polisi; b) Atau pegawai negeri sipil dalam lingkungan Kepolisian Negara dengan syarat sekurang-kurangnya berpangkat Pengatur Muda (Golongan II/a); c) Diangkat oleh Kepala Kepolisian Republik Indonesia atas usul komandan atau pimpinan kesatuan masing-masing; d) Penyidik Pegawai Negeri Sipil Penyidik Pegawai Negeri Sipil diatur dalam Pasal 6 ayat (1) huruf b KUHAP, yaitu pegawai negeri sipil yang mempunyai fungsi dan wewenang sebagai penyidik.

\section{Metode Penelitian}

Penelitian ini menggunakan metode kualitatif. Metode kualitatif adalah penelitian yang menghasilkan dan mengolah data yang sifatnya deskriptif, seperti transkripsi wawancara, catatan lapangan, gambar, foto rekaman video dan lain-lain (Hamidi 2010). Dalam penelitian kualitatif perlu menekankan pada pentingnya kedekatan dengan orang-orang dan situasi penelitian, agar peneliti memperoleh pemahaman jelas tentang realitas dan kondisi kehidupan nyata.

Informan diwawancarai secara mendalam yang berkaitan dengan permasalahan yang akan diteliti dan dibahas dalam penelitian ini. Peneliti memanfaatkan informan agar dalam waktu yang relatif singkat banyak informasi yang terjangkau (Basrowi \& Suwandi 2008). Berikut adalah informan dari penelitian ini: a) Kepala Unit PPA Polda Jatim; b) Penyidik Pembantu Unit PPA Polda Jatim; c) Pelaku anak; d) Orang tua/wali pelaku anak; e) Pendamping hukum anak Polda Jatim. Sementara itu, teknik analisis data yang digunakan dalam penelitian ini adalah menggunakan langkah-langkah seperti yang dikemukakan oleh Bungin (2003), yaitu sebagai berikut: (1) Pengumpulan data (data collection); (2) Reduksi data (data reduction); (3) Display data; (4) Verifikasi dan penegasan simpulan (Conclusion drawing and verification).

\section{Hasil dan Pembahasan}

\section{Faktor-faktor kejahatan oleh anak: Faktor perkembangan teknologi informasi}

Perkembangan teknologi informasi dewasa ini tidak dapat dihindari, dengan arus globalisasi yang memaksa orang untuk memahami teknologi. Perkembangan teknologi dan telekomunikasi tersebut telah merambah dalam elektronik. Hampir setiap orang telah menggunakan berbagai macam alat elektronik dalam kehidupan mereka sehari-hari. Bahkan sebagian manusia tidak dapat lepas dari alat elektronik tersebut. Perkembangan alat elektronik dan kemajuan teknologi dan telekomunikasi makin memudahkan manusia untuk tetap berhubungan meskipun berpisah bermil-mil jaraknya.

Perkembangan teknologi seperti pedang bermata dua. Ketika dipergunakan dengan baik maka perkembangan teknologi akan menjadi sesuatu hal yang positif sedangkan sebaliknya, apabila dipergunakan dengan maksud tertentu untuk hal yang merusak maka perkembangan teknologi tersebut menjadi sesuatu hal yang negatif. Salah satu hal yang kemudian berdampak negatif untuk anak-anak adalah masuknya informasi tanpa batas. 


\section{Faktor lingkungan}

Faktor ekstern yang menyebabkan maraknya kejahatan kesusilaan di bawah umur adalah karena faktor lingkungan. Di mana pun tempat tinggal anak jika memang lingkungan sekitarnya membebaskan anak-anak untuk bergaul dengan tidak benar, maka akan membuat anak-anak yang lain juga melakukan perilaku menyimpang.

\section{Faktor pola asuh orang tua}

Kejahatan asusila yang ditemukan di wilayah hukum Polda Jawa Timur, kemudian dinilai juga oleh ahli sebagai kelalaian orang tua anak-anak dalam hal penanaman nilai moral sejak kecil dengan baik. Pola asuh yang secara nyata membebaskan anak menggunakan teknologi tanpa pengawasan yang baik dan sesuai menyebabkan kejahatan anak atau di bawah umur kian meningkat, termasuk kejahatan asusila tersebut.

\section{Penyidik yang bertugas melakukan penyidikan adalah penyidik khusus anak atau penyidikan PPA}

Penyidikan terhadap anak dalam hal anak yang berkonflik dengan hukum dilakukan oleh penyidik anak, yang ditetapkan berdasarkan Surat Keputusan Kepala Kepolisian Negara Republik Indonesia atau pejabat yang ditunjuk olehnya. Penyidikan kasus anak harus dilakukan oleh unit PPA, karena SOP pelaksanaan penyidikan dirancang untuk menangani kasus di bawah umur yang akan mengedepankan diversi. Penyidikan oleh penyidik anak, berguna untuk melindungi hak tumbuh kembang anak dari trauma. Hal ini dikarenakan anak berhak untuk memperoleh perlindungan dari negara, tidak terkecuali pada anak yang terkait dengan kasus kejahatan asusila.

\section{Kurangnya kerjasama dan komunikasi antara unit PPA dan pemberi bantuan hukum}

Komunikasi merupakan faktor yang berperan penting sebagai acuan bagi implementator (pelaksana) kebijakan guna mengetahui apa yang harus dikerjakan, disamping itu juga sebagai perintah dari atasan terhadap implementator kebijakan sehingga komunikasi tersebut harus dinyatakan jelas, tepat dan konsisten dalam penerapan kebijakan agar tidak keluar dari sasaran yang hendak dicapai. Keberhasilan komunikasi dan kerjasama sebagai faktor penentu implementasi kebijakan ditentukan oleh bagaimana implementator memahami kejelasan isi pesan yang disampaikan untuk diteruskan pada pelaksana, selain itu juga kebijakan tersebut mendapat pengaruh yang kebijakan dilaksanakan dan karakter pelaksana.

Upaya yang dilakukan penyidik anak dalam hambatan mengenai perbedaan pemahaman dengan penyidik dan hakim pada penanganan perkara anak yang berkonflik dengan hukum yaitu melakukan komunikasi dengan penyidik dan pihak pemberi bantuan hukum apabila telah dilakukan proses penyidikan agar terwujudnya keadaan yang saling memahami perbedaan keyakinan penafsiran pasal satu sama lain.

\section{Sarana dan prasarana}

Penyediaan sarana dan prasarana khusus sangat dibutuhkan untuk mempermudah pemeriksaan anak, di mana terkait desain ruangan atau kenyamanan yang tidak gelap, tidak terlalu dingin, dan nyaman untuk anak atau remaja yang belum dewasa. Pada kajian umum mengenai penegakan hukum menjelaskan bahwa tanpa adanya sarana atau fasilitas tertentu, maka tidak mungkin penegak hukum akan berlangsung dengan lancar. Sarana untuk fasilitas tersebut, antara lain mencakup tenaga manusia yang berpendidikan dan terampil, organisasi yang baik, peralatan yang memadai, keuangan yang cukup dan lain-lain. Kalau hal-hal ini tidak terpenuhi maka mustahil peranan hukum akan mencapai tujuan. 


\section{Kesepakatan diversi antara kedua pihak tidak terwujud}

Ketika menentukan kesepakatan antara pihak korban dan pihak anak tidak mudah. Pada saat musyawarah diversi dilakukan ketika pihak anak yang berkonflik dengan hukum dan pihak korban bertemu di ruang diversi sering terjadi pertengkaran atau keributan yang mengakibatkan musyawarah diversi menjadi tidak kondusif.

Keluarga korban tidak ingin sepakat dengan cara diversi atau mengindari pidana, karena alasan keadilan. Hal ini dapat diartikan bahwa perbedaan kepentingan antara keduanya merupakan masalah mendasar dalam penentuan kesepakatan, terkadang permintaan pihak korban tidak dapat dipenuhi oleh pihak anak yang berkonflik dengan hukum karena syarat-syarat yang diajukan oleh pihak korban dianggap terlalu berlebihan namun pihak korban pun tidak ingin mengubah persyaratan kesepakatannya sehingga pelaksanaan diversi gagal dilakukan.

\section{Simpulan}

Penerapan diversi sebagai bentuk penyelesaian perkara pidana anak di tingkat penyidikan dalam kasus kejahatan kesusilaan di wilayah hukum Polda Jatim yaitu penyidik yang bertugas melakukan penyidikan adalah penyidik khusus anak atau penyidikan PPA; pelaksanaan penangkapan; penahanan; pemeriksaan anak dilakukan dalam suasana kekeluargaan; penyidik wajib meminta pertimbangan atau saran dari pembimbing kemasyarakatan, dan apabila perlu juga dapat meminta pertimbangan atau saran dari ahli pendidikan, ahli kesehatan jiwa, ahli agama, atau petugas kemasyarakatan lainnya; hak mendapat bantuan hukum dan bantuan lainnya dan penyidikan anak wajib dirahasiakan. Faktor penghambat dalam penerapan diversi sebagai bentuk penyelesaian perkara pidana anak di tingkat penyidikan dalam kasus kejahatan kesusilaan di wilayah hukum Polda Jatim adalah faktor internal dan eksternal.

Pihak kepolisian melakukan pelatihan-pelatihan kepada penyidik PPA terkait pelaksanaan diversi. Selain itu, pihak kepolisian melakukan koordinasi berupa pertemuan dengan pihak Komisi Perlindungan Anak Indonesia mengenai kerja sama dalam melaksanakan diversi. Diharapkan dengan ditingkatkannya kerja sama antara kepolisian dan Komisi Perlindungan Anak Indonesia, maka diversi terlaksana dengan baik dan sukses.

\section{Daftar Pustaka}

Atmasasmita R (1983) Problem Kenakalan Anak-Anak Remaja. Bandung: Armico.

Basrowi \& Suwandi (2008) Memahami Penelitian Kualitatif. Jakarta: Rineka Cipta.

Bungin B (2003) Analisis Data Penelitian Kualitatif. Jakarta: PT. Raja Grafindo Persada.

Edyanto N (2017) Restorative justice ntuk menyelesaikan kasus anak yang berhadapan dengan hukum. Jurnal Ilmu Kepolisian 11 (3):39-46.

Ernis Y (2016) Diversi dan keadilan restoratif dalam penyelesaian perkara tindak pidana anak di Indonesia. Jurnal Ilmiah Kebijakan Hukum 10 (2):163-174.

Hadisuprapto P (2010) Delikuensi Anak Pemahaman dan Penanggulangannya. Malang: Selaras.

Hambali AR (2019) Penerapan diversi terhadap anak yang berhadapan dengan hukum dalam sistem peradilan pidana. Jurnal Ilmiah Kebijakan Hukum 13 (1):16-29.

Hamidi (2010) Metode Penelitian dan Teori Komunikasi. Malang: Universitas Muhammadiyah Malang Press.

Harahap MY (2005) Pembahasan Permsalahan dan Penerapan KUHAP, Penyidikan dan Penuntutan. Jakarta: Sinar Grafika.

Harahap HP (2014) Tinjauan yuridis sosiologis terhadap kebijakan diversi bagi anak dalam undangundang nomor 11 tahun 2012 tentang sistem peradilan pidana anak. Unnes Law Journal 3 (1):10-19.

Hartono B (2015) Penyelesaian perkara melalui diversi sebagai upaya perlindungan anak pelaku tindak pidana. Pranata Hukum 10 (1):75-85. 
Marlina (2008) Penerapan konsep diversi terhadap anak pelaku tindak pidana dalam sistem peradilan pidana anak. Jurnal Equality 13 (1):96-108.

Marlina (2010) Pengantar Konsep Diversi dan Restorative Justice dalam Hukum Pidana. Medan: USU Press.

Mimi U, Pello J \& Medan K (2014) Diversi dalam perlindungan hukum anak yang bermasalah hukum dalam sistem peradilan pidana anak. Masalah - Masalah Hukum 43 (2):305-312.

Munajah (2015) Upaya diversi dalam proses peradlan pidana anak Indoonesia. Al'Adl 7 (14):28-34.

Plantika Y (2019) Faktor penyebab perdagangan orang di wilayah hukum Polres Malang Kota. Jurnal Sosiologi Dialektika 14 (1):9-15.

Pratama RH, Sulastri S \& Darwis RS (2008) Perlindungan terhadap anak yang berhadapan dengan hukum. Prosiding KS: Riset \& PKM 2 (1):8-13.

Pratama NR (2018) Diversi terhadap anak pelaku tindak pidana dalam sistem peradilan pidana anak. Aktualita 1 (1):242-260.

Priamsari PA (2018) Mencari hukum yang berkeadilan bagi anak melalui diversi. Jurnal Law Reform 14 (2):220-235.

Rahmat DA (2019) Disparitas penerbitan Surat Izin Mengemudi sebagai pemenuhan hak bagi penyandang tunarungu. Jurnal Sosiologi Dialektika 14 (1):26-33.

Ratomi A (2013) Konsep prosedur pelaksanaan diversi pada tahap penyidikan dalam penyelesaian tindak pidana yang dilakukan oleh anak. Arena Hukum 6 (3):394-407.

Rosyidah N (2012) Pembaharuan ide diversi dalam implementasi sistem peradilan anak di Indonesia. Masalah-Masalah Hukum 41 (2):179-188.

Soesilo R (1994) Kitab Undang-Undang Hukum Pidana Serta Kome ntar Lengkap Pasal Demi Pasal. Bogor: Politeia.

Sosiawan UM (2016) Perspektif restorative justice sebagai wujud perlindungan anak yang berhadapan dengan hukum. Jurnal Penelitian Hukum 16 (4):425-438.

Stickland RA (2004) Restrorative Justice. New York: Peter Lang Publishing.

Subekti (2003) Pokok-Pokok Hukum perdata. Jakarta: PT. Intermasa.

Wartono NE (2019) Pengawasan penggunaan senjata api legal di wilayah hukum Kepolisian Daerah Metro Jaya. Jurnal Sosiologi Dialektika 14 (1):1-8.

Wicaksono AH \& Pujiyono (2015) Pembaharuan ide diversi dalam implementasi sistem peradilan anak di Indonesia. Jurnal Law Reform 11 (1):12-42.

Yudaningsih LP (2014) Penanganan perkara anak melalui restorative justice. Jurnal Ilmu Hukum. Fakultas Hukum Universitas Jambi:67-79. 